\title{
A Study of Stationers Attractiveness Factors
}

\author{
Jia-Xuan, Han *a \\ Department of Industrial Design \\ National Cheng Kung University \\ Tainan 70101, Taiwan R, O, C \\ hanjiaxuan66@gmail.com
}

\author{
Min-Yuan Ma** \\ Department of Industrial Design \\ National Cheng Kung University \\ Tainan, Taiwan, R, O, C \\ mamy@mail.ncku.edu.tw
}

\begin{abstract}
As the changes in consumption patterns and impacts from the e-commerce, the operation conditions of stationers has gone from bad to worse day by day, and how to find the charming factors of the physical stores of stationers to attract consumers becomes the impendent topic faced by the entity stores of the stationers. And as the promotion of material conditions, the material needs of stationeries of people have gradually risen to the mental needs, thus to seek for the interest and perception of consumers to the stationers, researches must be done on the inner demands of consumers and the groups with a high involvement degree. Thus the charms of stationers could be found, stationers that can satisfy and move the consumers could be designed and the commercial value of their existence could be found.
\end{abstract}

Through operation of miryoku engineering evaluation grid method, 10 intelligent persons with special interests on the stationers were interviewed in this research, namely 5 males and 5 females, and the charming factors of stationers in their mind were caught. To make the charming factors more accurate and representative, the charming factors would be simplified with the KJ method in this research, and 6 abstract feelings including [the sense of warmth], [the sense of intimate], [the sense of concision], [the sense of relaxation], [the sense of relieving] and [the sense of joy] were summarized and settled to be the principal axis of the questionnaires in the next stage to enlarge the collection of data. At last, through issuing of questionnaires and statistical analysis of quantification theory type I, the degree of correlation between the 6 abstract feelings and the stationers and the weight of affections of each project (original evaluation projects) and category (detailed evaluation projects) can be grasped.

It is hoped that the results through research and discussion on the charming factors of stationers could give more practical suggestions and helps to the industry, and hope that this research could provide references for the relative industries like stationers, etc. to improve the attractiveness.

Keywords-Stationery 、Miryoku Engineering 、Evaluation Grid Method 、Quantification Theory Type I

\section{INTRODUCTION}

Jing-Song Huang, etc. (2005) mentioned that charm was a kind of attractiveness and affection, and for products, charm was a force that attracted and affected consumers, it could enable the products to have peculiarities including pleasing styles, tastes and textures, etc., and these peculiarities could make the products attract the sights of consumers. The charming factors of the products themselves can have decisive affections on the consumers, and charming factors not only come from the functions of the products themselves, they also include the factors like external services and space environment, etc. The charm of products can affect the interest of consumers, and the degree of interest has a great correlation with the attractiveness of consumers, thus the discussion on the charm factors of stationers is especially important for the development direction of stationers in the future.

\section{LITERATURE REVIEW}

\section{A. Trends in stationery shops}

Yi-Ru Chen (2014) discusses the use of today's stationery products for its consumers, is no longer simply as writing, office appliances, but a way of life portrayal by the combination of living aesthetics and stationery shop can be effective To attract the attention of consumers, Eslite know that only the changes are not able to move the consumer, so through the creation of environmental ambience, so that consumers experience the consumption experience through the aesthetic.

Chong-Ren Hsu (2017) refers to the merchandise in the store, from the refrigerator, bicycles, furniture, stationery, clothing, books ....... to sit down and have a cup of coffee, open the menu of Muji, All the activities are met. Seemingly dazzling, but rational, moderation, minimalist, straight into the spirit of customer needs, through everything. It can be said that the sale of printed products is a full range of life proposals, leading the city people to the original life of the yearning, or create a new type of life.

Genko Katsuyama (2014) presents Tokyo's independent bookstore, through art activities, text creation, and memory with consumers. To enhance the competitiveness and charm, different from the large chain of bookstores, independent bookstores distinctive characteristics, collection of specific areas of the collection, for different types of readers to bring a sense of belonging. In Taiwan has gradually sprouted from the independent bookstore deep plowing spirit, and create a new type of lifestyle and bookstore boom.

\section{B. Miryoku Engineering}

Min-Yuan Ma (2007) mentions that "charm" is an enzyme that promotes human civilization, social development, life and movement, and is closely related to human life and an 
important connotation and motivation in life. The term "glamorous engineering" was developed by the Japanese scholar Junichiro Sanui and Masao Inui in 1985 by reference to the clinical psychologist Kelly's concept of "The Psychology of Personal Constructs" Mainly to capture the concept of personal awareness and list of finishing methods.

Min-Yuan Ma et al. (2007) argue that the charismatic engineering evaluation constructor is a suitable and effective qualitative research tool.

Chung-Che $\mathrm{Lu}$ (2010) mentions that the "emotional" experience can arouse consumers' potential sensory pleasures and the desire to meet their dreams, and explore the glamor of pleasure products.

Ujigawa (2000) mentions that the theoretical basis of the study of glamor is mainly based on the following three points: basic theoretical doctrine, shape (research and analysis techniques) and design, as described in Table 1.

Table 1 Basic of Miryoku Engineering (Ujigawa, 2000)

\begin{tabular}{|c|c|c|c|}
\hline Area & Peculiarity & $\begin{array}{l}\text { Concept, theory } \\
\text { and method }\end{array}$ & \\
\hline \multirow[t]{4}{*}{ Basic theories } & Definition & $\begin{array}{l}\text { Inclusive } \\
\text { recognition }\end{array}$ & \\
\hline & Recognition & $\begin{array}{l}\text { Pattern } \\
\text { recognition }\end{array}$ & \\
\hline & Learning & $\begin{array}{l}\text { Fashion, } \\
\text { Character goods }\end{array}$ & \\
\hline & Value system & Reference group & \\
\hline \multirow[t]{4}{*}{ Modeling } & $\begin{array}{l}\text { Structure } \\
\text { identification }\end{array}$ & Depth interview & $\begin{array}{l}\text { Evaluation grid } \\
\text { method }\end{array}$ \\
\hline & & & $\begin{array}{l}\text { Paired } \\
\text { comparison } \\
\text { Regression } \\
\text { analysis } \\
\text { Conjoint } \\
\text { analysis }\end{array}$ \\
\hline & $\begin{array}{l}\text { Parameter } \\
\text { identification }\end{array}$ & Composite effect & \\
\hline & Segmentation & Cluster analysis & \\
\hline \multirow{4}{*}{ Design } & Planning & On- site thinking & Scenario \\
\hline & Framming & Ü- SIL UIIIKIII & making \\
\hline & Design strategy & Positioning & Cognitive map \\
\hline & Materializing & $\begin{array}{l}\text { Prototype } \\
\text { creation }\end{array}$ & $\begin{array}{l}\text { User } \\
\text { participation }\end{array}$ \\
\hline
\end{tabular}

Chung-Che Lu (2010) argues that charisma is the designer's method of helping to master consumer thinking, helping designers closer to the needs of consumers and proposing more intimate perceptual design elements.

Lin, Y. C. (2014) proposed a charismatic engineering evaluation structure (QTTI) that perfume shape and shape design affect consumer decision-making. It can help product designers get the most in line with the expectations of consumers the best design. This new approach to consumers provides an effective mechanism for promoting new product design processes and development.

\section{RESEARCH METHODOLOGY}

\section{A. KJ Method}

Kawakita Jiro ((かわきたじろう，1920-2009), a cultural anthropologist who was founded by the Japanese scholar
Kawakita (1964), was founded as a professor at Tokyo University of Technology. From the years of fieldwork experience in 1964 put forward a set of methods: "from the chaotic state, the diverse and complex facts, opinions or creative thinking about the language information, a card to a card card, and then according to the card The combination of the affinity and similarity, layer by layer, to make it structured and create a creative and unified problem-solving concept "is a different nature of the information and information to be summarized in the unified techniques, the implementation of the steps that order As shown in Table 2.

Table 2 The step instructions of KJ method

\begin{tabular}{cc}
\hline Step instructions & Description \\
\hline $\begin{array}{c}\text { 1.Card making } \\
\begin{array}{c}\text { 2.Grouping and } \\
\text { naming }\end{array}\end{array}$ & $\begin{array}{c}\text { Determine a focus question and put opinions or data } \\
\text { onto sticky notes. Put sticky notes on the wall } \\
\text { Group similar items and naming each group. }\end{array}$ \\
4.Chart making & $\begin{array}{c}\text { Put the card or label on the paper, and then use it on } \\
\text { the top of the second stage above the group set up, } \\
\text { and add the title. The relationship between circles } \\
\text { and circles is illustrated graphically. } \\
\text { We will voting for the most important groups. } \\
\text { Finally we will ranking the most important groups }\end{array}$ \\
\hline
\end{tabular}

\section{B. Evaluation Grid Method}

The Evaluation Grid Method is an important method about Miryoku Engineering, which was improved in two steps by Sanui and Inui (1986) from the Repertory Grid Method (RGM). It could help scholars to understand the subject's psychological cognitive level of a thing. It is a qualitative research method. Through this method, the abstract psychological feelings and specific subtle conditions, which elusive capture in usual, can be extracted. Moreover, Lin, Lin and Ma (2007) indicate, Evaluation Grid Method is an appropriate and effective method of qualitative research.

The first step is to answer like or not by evaluation of the target. The second step is a process to clarify the meaning and status of the answer by additional question. Through iterative Laddering to understand the abstract feelings, initial reasons and concrete reasons( $\mathrm{Ma}, 2010)$.

\section{Quantification Theory Type I (QTT1)}

In this study, the Quantitative Theory I would be used to understand the relationship among stationers, relieve stress and impact emotion. Classify the important attractive factors of stationers. Quantitative Theory I is one of the Categorical Multiple Regression Analysis Methods, which always used in Kansei Engineering. The main purpose for the sake of a variable approximate function relation between various other qualitative project teams and to determine the quality of each item for the purposes of variables affect the strength of the use of multiple regression analysis. Designers could base on abstract psychological feelings and specific form elements to be combined into a specific feature construction. Create a specific product image, so that, you can focus on the design for a particular image to increase the degree of consumer preferences for products. The function formula (1) is as follows: 


$$
\mathrm{Y}=\sum \beta X+\theta
$$

Finally, we get the partial correlation coefficient: the weight of each element on the whole relationship. Determine the coefficient: is the basis for the reliability of the statistical results. And through the correlation analysis, can calculate the $\mathrm{R}$ value. $\mathrm{R}=0.00 \sim 0.19$ showed a low correlation, $0.20 \sim$ 0.39 predicted correlation with $0.40 \sim 0.69$, and $0.70 \sim 0.10$ predicted that there was a strong correlation.

\section{VERIFICATION AND ANALYSIS}

\section{A. Research process and steps}

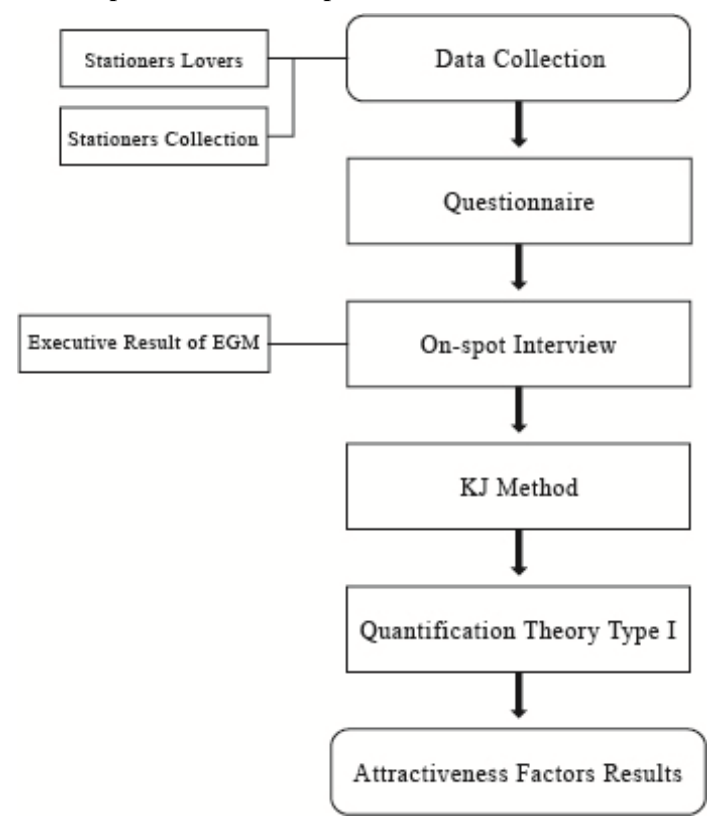

Figure 1 Research Flow Diagram

The research was mainly divided into the following 4 steps (1) questionnaire: issue the "stationery fan seeking plan" with the method of questionnaire, and finally selected 10 persons with high involvement in the stationers as the interview objects, (2) on-spot interview: conduct interviews for 10 persons with high involvement in the stationers with the evaluation grid method (EGM). The main concept of this EGM lies in the deep-through interviews for the groups with high involvement of stationers, it compares the characters of the stationers from the actual thoughts of consumers and settles an opinion that is admitted to the public, and even the abstract feelings that are difficult to analyze like the sense of warmth or relaxation can be analyzed with the EGM of miryoku engineering; (3) KJ method: conduct summary and settlement and summarize 13 kinds of image vocabularies, and finally make it into a unified evaluation grid drawing. (4) Qualification theory type I: conduct secondary questionnaire for the charm of stationers, finally conduct analysis for the results of the questionnaires through the method of qualification theory type I, find out the degree of correlation between the abstract feelings and charming factors of the stationers and the weight of affections of each project (original evaluation projects) and category (detailed evaluation projects).

\section{B. Research steps}

After establishing the research direction and theme, this study is mainly based on EGM qualitative interview, KJ method, quantitative analysis of a class to carry out.

\section{1) EGM execution}

An interview with the evaluation of the construction of the high-involvement group of 10 stationery shops (EGM) was conducted to obtain qualitative information. In this study, according to the actual interview case of stationery consumers, through the comparison of the characteristics of the comparison, sort out a true and credible evaluation and opinions; first selected the respondents to stimulate the experimental stimulus, first selected representative of the stationery shop Pictures, and arranged the ideal of the stationery shop ranking order; and then interview.

Interview by asking "the difference between the first and second reasons why the discussion," the respondents answer "I think the first brand of goods is not complicated models", the "product style is not complicated," extracted as the charm of the original Reason, and then ask, "What do you think is not complicated style will be attractive?" If the respondents answer "I like the basic models, simple style", then the "basic section" into the charm of specific factors; Continue to ask, "Where do you think the basic section will attract you? Can you describe it?" Respondents who answered "Easy to use and easy to use" will be "easy to use" and "relaxed" Charm abstract factor. To obtain qualitative information, and the results of the interview made into a personal evaluation structure map.

\section{2) KJ execution}

Even if it is difficult to capture the abstract feelings and specific conditions of the corresponding relationship, can be used to compile this method, and the results of the interview made into a personal evaluation structure map. Finally, the use of KJ method to sum up the fresh, sense of value, convenience, warmth, atmosphere, pure, exclusive sense, noble, relaxed, peace of mind, rich feeling, pleasure, intimate, for the three kinds of imagery vocabulary and three major impact stationery The facade of charm. As shown in Figure 2, Figure 3 and Figure 4. For the stationery shop space, quality, selling products for interviews and finishing.

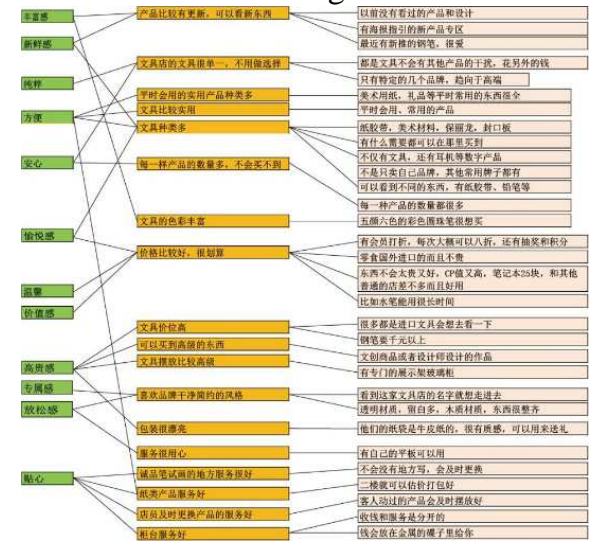

Figure 2The evaluation of the quality of the stationers 


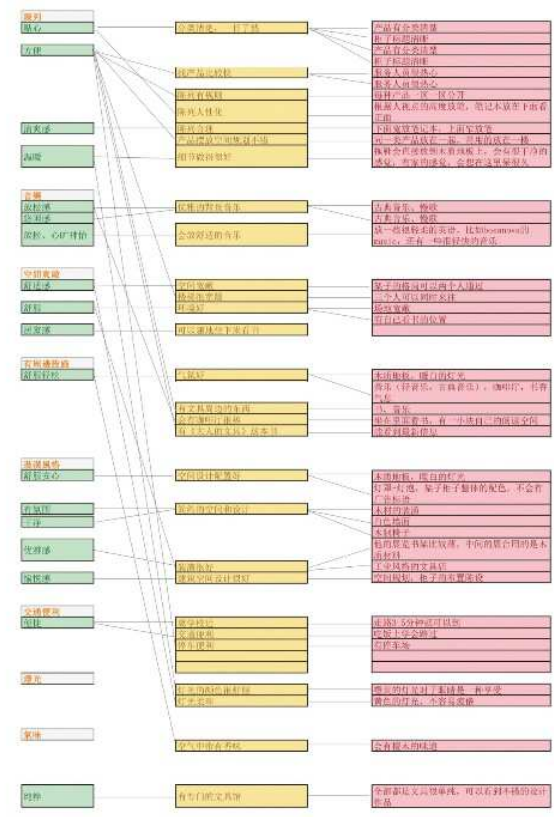

Figure 3The evaluation of the environment of the stationers

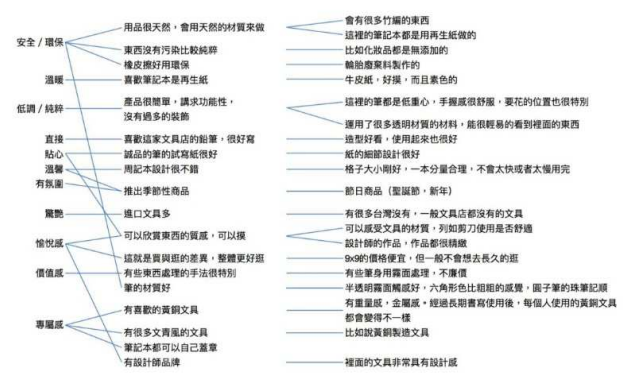

Figure 4 The evaluation of the products of the stationers

3) Executive of Quantification Theory Type I

Through the EGM that the relevant questionnaire results, $\mathrm{Y}$ is the predicted value:

$Y=\alpha_{11} x_{11}+\alpha_{12} x_{12}+\alpha_{21} x_{21}+\alpha_{21} x_{22} \mathrm{Y}=\alpha \_11 \mathrm{X} \_11+$ $\alpha \_12 X \_12+\alpha \_21 X \_21+\alpha \_21 X \_22$, where aij is called the category score or the coefficient of the dummy variable. The sum of $Q=\left(\right.$ external reference $Y^{\wedge}{ }^{\prime}$ - prediction value $\left.Y^{\wedge}\right) 2$ is minimized, and the result is obtained. It can be understood that the effect of $X_{-} \_1$ on the external benchmark $Y^{\wedge}$ 'is greater than X_2. Finally to write into EXCEL do automated calculation, as shown in Figure 5.

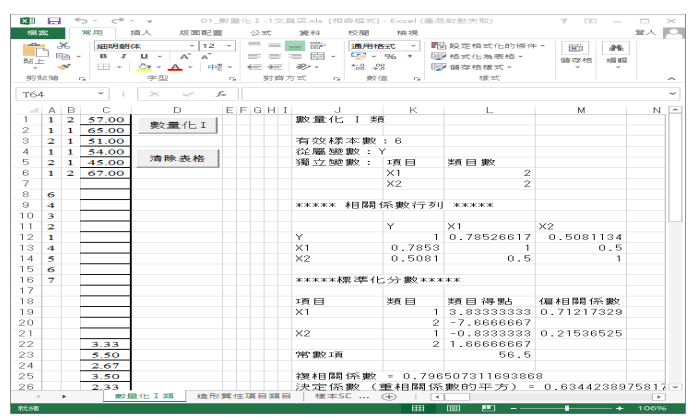

Figure 5

\section{CONCLUSIONS AND SUGGESTIONS}

\section{A. EGM Execution Results}

As is shown in the evaluation grid drawings of the 3 aspects, good C/P and services will bring people a sense of convenience, intimation and dignity; a good space environment and surrounding can bring people the sense of relaxation, warmth and convenience; good products in the stores can bring people a sense of safety, joy and belonging.

The quantitative statistics on the abstract feelings (superior) is shown in the following table 3 , combined with the 3 charming aspects, 6 abstract feelings including [the sense of warmth], [the sense of intimate], [the sense of concision], [the sense of relaxation], [the sense of relieving] and [the sense of joy] were selected to make the evaluation grid drawing of the 6 feelings and made preparations for the following quantification theory type I. find out the correlation degree between the 6 abstract feelings and the stationers and the weight of affections of each project (original evaluation projects) and category (detailed evaluation projects).

Table 3The statistical results of 13 images

\begin{tabular}{|c|c|c|c|c|c|c|c|c|c|c|c|c|c|}
\hline P N & 1. & 2. & 3. & 4. & 5. & 6 & 7. & 8. & 9. & 10. & 11 & 12. & 13 \\
\hline Image & fresho & valuee, & corveniences & warmth & Good-atmosphere & pures & exdusiver & \begin{tabular}{|l|l} 
grandeur \\
|
\end{tabular} & relaxe & relieved & plentifule & happy= & sweat \\
\hline scoree & 4 & 30 & $13 \%$ & 70 & 4 & 4 & 90 & 50 & 20 & 50 & 60 & 40 & 30 \\
\hline Rankinge" & 60 & 70 & 10 & 30 & 60 & 6. & 20 & 50 & 8 & ${ }_{50}$ & 4 & 60 & 7 \\
\hline
\end{tabular}

\section{B. Executive Result of Quantification Theory Type I}

Conduct secondary questionnaire for the 6 abstract feelings, conduct analysis of quantification theory type I for the results of the questionnaire, based on the results of analysis of quantification theory type $\mathrm{I}$, if the point of invocation of a category is positive, the project corresponding to this category has a positive effect, that is, if adding in this characteristic factor when building a good stationer, it will have a promotion function for the corresponding charm of the stationer, and among which those with the point of invocation of a category is $>0.3$ will have an obvious effect. Thus the summary and collection of categories with positive points of invocation is shown as Figure 6.

\begin{tabular}{|c|c|c|c|c|}
\hline \multirow{9}{*}{ 温警感 } & 項目 & 類目 & 類目得點 & 偏相關係數 \\
\hline & \multirow{4}{*}{ X1-在家的感睍 } & 1. 木晢的地扳 & -0.67 & \multirow{3}{*}{0.90} \\
\hline & & 2. 可以隨地坐下來看書 & 0.83 & \\
\hline & & 3. 放在木樫地板上的挴鈢 & -4.17 & \\
\hline & & 4. 橙满色的燈光 & -2.17 & \\
\hline & \multirow{4}{*}{ X2-痤品設計 } & 1. 有推出奉䬫性的商品 & -0.97 & \multirow{4}{*}{0.66} \\
\hline & & 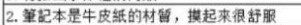 & 0.37 & \\
\hline & & & -0.63 & \\
\hline & & 4. 筆記本的霄錗和其他間差不多, 而且好用 & 0.87 & \\
\hline
\end{tabular}

\begin{tabular}{|c|c|c|c|c|}
\hline \multirow{11}{*}{ 貼心感 } & 項目 & 類目 & 類目得點 & 偏相關係數 \\
\hline & \multirow{3}{*}{ 店面陳列 } & 文具的分類清琶 & 0.38 & 0.36 \\
\hline & & 展示掼的摽题設胡合理 & -0.04 & \\
\hline & & 根據視湶的高度骤放文具 & -0.42 & \\
\hline & \multirow{4}{*}{ 䂣用體铪 } & 可以照受文具的材筸 & 0.18 & 0.54 \\
\hline & & 可以鹳用拆封的文具 & 0.05 & \\
\hline & & 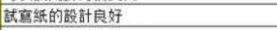 & -1.37 & \\
\hline & & 即時更換蒠滿的試葛纸 & 0.70 & \\
\hline & \multirow{3}{*}{ 服務態度 } & 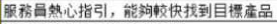 & 0.05 & 0.48 \\
\hline & & 曾即時整理客人動通的産品 & -0.80 & \\
\hline & & 找零會放在金属托桖给客人 & 0.92 & \\
\hline
\end{tabular}




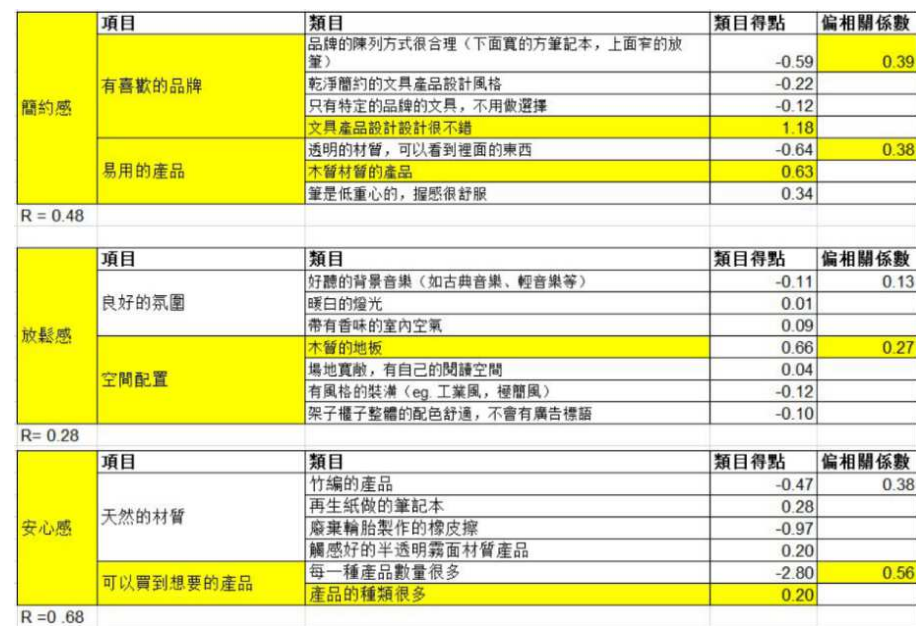

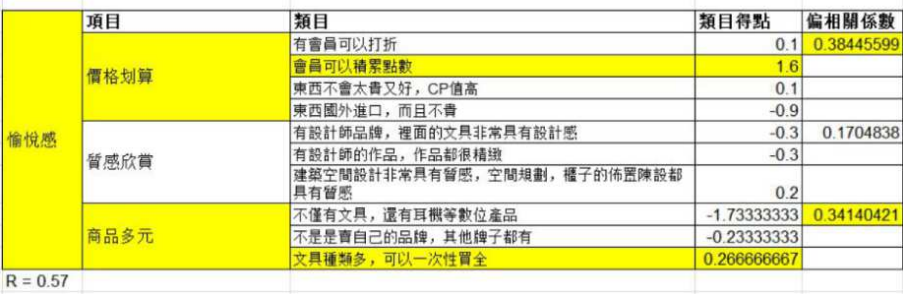

Figure 6 Analysis Graphics of Quantification Theory Type I of the Stationers

As is shown in the above figure, the sense of intimation has a strong correlation with the services of the stationers, and it is an important weight $(\mathrm{R}=0.62 /$ coefficient of partial correlation: $0.48 /$ point of invocation of category: 0.92 ) to build the sense intimation if the changes are put on the metal trays; the sense of warmth has a strong correlation with the space environment of the stationers. A sense of home, and the effect that people can sit down at wills on the ground to read books ( $R=0.68$ / coefficient of partial correlation: $0.56 /$ point of invocation of category: 0.2 ) are important weights to build the sense of warmth. The results showed that improving the service attitude when shopping in the stationers can make consumers feel intimate; build a sense of home in the shopping environment, and make the consumers feel warm; commodities that different consumers want to buy can be bought from the stationers, and thus building the sense of relieve in shopping. If the above factors are done, it will be the source of the charms of stationers for the consumers.

\section{Summary}

The degree of correlation between the abstract feelings of consumers and the charming factors of the stationers can be known from the result of this research, and the charming factors of stationers towards consumers can be found through the miryoku engineering research method. The evaluation grid drawing of the stationers was further collected through interviews with several consumers. It was found through research that the 6 charming feelings that attract the consumers to the stationers were respectively [the sense of warmth], [the sense of intimate], [the sense of concision], [the sense of relaxation], [the sense of relieving] and [the sense of joy]. The calculated the weight of affection of each project (original evaluation projects) and category (detailed evaluation projects) with the quantification theory type I, and the result of correlation between them could also be known. The result of statistical analysis showed that, [the sense of warmth] was the most important charming sense of the stationers for people who go to stationers frequently, it could be seen from this that warm services and environment need to be given to the consumers when building them in the stationers, make people feel at home, and they can sit down on the floor to read books at wills. The significant point of this research was the application of miryoku engineering theory and evaluation grid method, thus the charming factors of the products/services towards the consumers could be easily selected. Assistance can also be given to the management staff, engineers, sales planners or designers to step into the experience of consumers, and explore the sensory value and charm of the objects.

\section{References}

[1] Chong-Ren Hsu, 2017. Innovation, from the beginning. CommonWealth Magazine. ISBN: 9789863982425

[2] Chung-Che Lu, Min-Yuan Ma, 2010. Research on the Attractive Factors of Pleasurable Products and Pleasure Durability. Department of Industrial Design, National Cheng Kung University, Tainan 70101, Taiwan

[3] Genko Katsuyama, 2014. TOKYO BOOKSTORE GUIDE. Cite Media Holding Group All Rights Reserved, Taiwan. ISBN: 9789863061250

[4] Jing-Song Huang, June-Yi Su, Min-Yuan Ma, 2005 , The sunglasses Based on Miryoku Engineering. The 10th Chinese Institute of Design Study Forum and Conference, 2005. Taipei. pp. 431-436.

[5] Lin, Y. C., \& Wei, C. C., 2014. The QTTI-Based TOPSIS Decision Support Model to Fragrance Form Design. Paper presented at the 2014 International Symposium on Computer, Consumer and Control.

[6] Min-Yuan Ma, Li-Tan Tseng, 2007. The Sightseeing Festival Industry of Attractiveness Factors in Taiwan- Case Study on The Yilan International Children's Folklore and Folk-game Festival. The 12th Chinese Institute of Design Study Forum and Conference- Forwardlooking design: integration of technology and humanities (CD-ROM Proceedings), 2007.

[7] Ujigawa, M., 2000. The evolution of preference-based design, Research and Development Institute.

[8] Yi-Ru Chen, 2014. Study on Consumers' Lifestyle Aesthetic, the case of Eslite Stationery Specialty Store in Taipei. National Taipei University of Education Available from Airiti Airiti Library database. 